\title{
Emission quantification using the tracer gas dispersion method: The influence of instrument, tracer gas species and source simulation
}

Delre, Antonio; Mønster, Jacob; Samuelsson, Jerker; Fredenslund, Anders Michael; Scheutz, Charlotte

\section{Published in:}

Science of the Total Environment

Link to article, DOI:

10.1016/j.scitotenv.2018.03.289

Publication date:

2018

Document Version

Peer reviewed version

Link back to DTU Orbit

\section{Citation (APA):}

Delre, A., Mønster, J., Samuelsson, J., Fredenslund, A. M., \& Scheutz, C. (2018). Emission quantification using the tracer gas dispersion method: The influence of instrument, tracer gas species and source simulation. Science of the Total Environment, 634, 59-66. https://doi.org/10.1016/j.scitotenv.2018.03.289

\section{General rights}

Copyright and moral rights for the publications made accessible in the public portal are retained by the authors and/or other copyright owners and it is a condition of accessing publications that users recognise and abide by the legal requirements associated with these rights.

- Users may download and print one copy of any publication from the public portal for the purpose of private study or research.

- You may not further distribute the material or use it for any profit-making activity or commercial gain

- You may freely distribute the URL identifying the publication in the public portal 
1 Emission quantification using the tracer gas dispersion method: the influence of

2 instrument, tracer gas species and source simulation

3

4 Antonio Delre ${ }^{\mathrm{a}}$, Jacob Mønster ${ }^{\mathrm{b}}$, Jerker Samuelsson ${ }^{\mathrm{c}}$, Anders M. Fredenslund ${ }^{\mathrm{a}}$, 5 Charlotte Scheutz ${ }^{\text {a }}$ *

6

7 a Department of Environmental Engineering, Technical University of Denmark,

8 Bygningstorvet, Bygning 115, 2800 Kgs. Lyngby, Denmark

$9 \quad{ }^{\mathrm{b}}$ FORCE Technology, Park Alle 345, 2605 Brøndby, Denmark

$10{ }^{\mathrm{c}}$ FluxSense AB, SE-41296 Göteborg, Sweden

11 *Corresponding author: chas@env.dtu.dk

13 Highlights

- Emission rates varied up to $18 \%$ when multiple analytical instruments were used

- The analytical instrument should have good precision and high detection frequency

- The ratio of the tracer gas release rate to instrument precision should be high

- Upwind tracer gas misplacement results in emission measurement errors of up to $50 \%$

\section{ABSTRACT}

The tracer gas dispersion method (TDM) is a remote sensing method used for quantifying fugitive emissions by relying on the controlled release of a tracer gas at the source, combined with concentration measurements of the tracer and target gas plumes.

24 The TDM was tested at a wastewater treatment plant for plant-integrated methane 
25 emission quantification, using four analytical instruments simultaneously and four different tracer gases. Measurements performed using a combination of an analytical

27 instrument and a tracer gas, with a high ratio between the tracer gas release rate and 28 instrument precision (a high release-precision ratio), resulted in well-defined plumes

29 with a high signal-to-noise ratio and a high methane-to-tracer gas correlation factor.

30 Measured methane emission rates differed by up to $18 \%$ from the mean value when

31 measurements were performed using seven different instrument and tracer gas

32 combinations. Analytical instruments with a high detection frequency and good

33 precision were established as the most suitable for successful TDM application. The

34 application of an instrument with a poor precision could only to some extent be

35 overcome by applying a higher tracer gas release rate. A sideward misplacement of the 36 tracer gas release point of about $250 \mathrm{~m}$ resulted in an emission rate comparable to those

37 obtained using a tracer gas correctly simulating the methane emission. Conversely, an

38 upwind misplacement of about $150 \mathrm{~m}$ resulted in an emission rate overestimation of

39 almost $50 \%$, showing the importance of proper emission source simulation when 40 applying the TDM.

42 Keywords: Diffusive emissions, multiple analytical instruments, release precision ratio, 43 tracer misplacement error, emission factors, wastewater treatment 


\section{Graphical abstract}

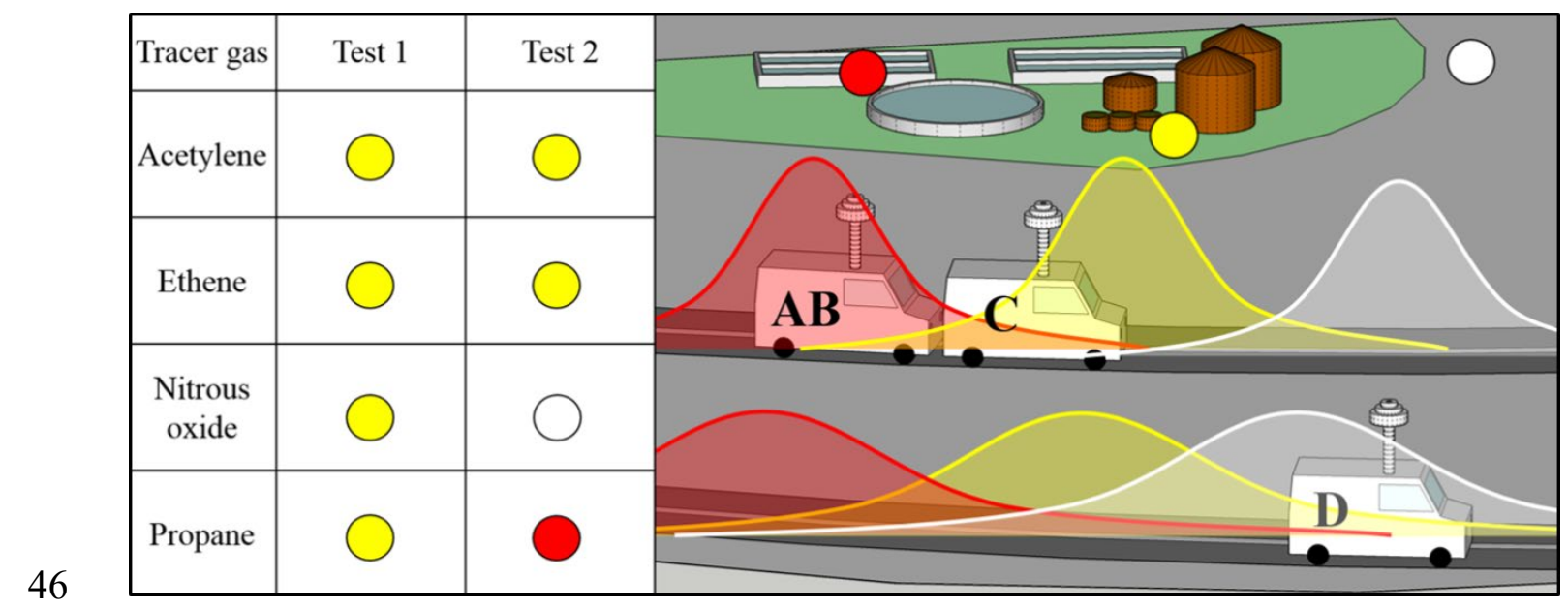




\section{Introduction}

Anthropogenic methane emissions into the atmosphere are important drivers of climate change (IPCC, 2013). Quantifying these methane emissions is important for assessing the contribution of various methane emission sources as well as forming the basis for emission mitigation actions. Recently, the tracer gas dispersion method (TDM) has been adopted for quantifying fugitive methane emissions from area sources in both Europe and the United States (Delre et al., 2017; Jakober et al., 2014; Mitchell et al., 2015; Mønster et al., 2015; Reinelt et al., 2017), and the Danish Environmental Protection Agency currently recommends its use for landfill methane emission quantification, resulting in a method that is routinely applied (DEPA, 2006). The United States Environmental Protection Agency also promotes TDM development (designated EPA Category C "other test method" (OTM) 33B) as a standard method for plantintegrated and area source emission measurements (Foster-Wittig et al., 2015). The TDM combines tracer gas release and downwind gas concentration measurements across the plume, and thus long-lived atmospheric tracer gases are required, in order to maintain a constant concentration ratio between the target and tracer gases during atmospheric dispersion (Lamb et al., 1995; Stiversten, 1983). The target gas emission rate is obtained by multiplying three factors, namely the tracer gas mass release rate, the downwind concentration ratio of the target and tracer gases above background level and the ratio of the target and tracer gases' molecular weights (Galle et al., 2001). Originally, a TDM was employed by using static atmospheric sampling points across the plume, followed by subsequent gas sample analysis (Stiversten, 1983). Recently, analytical instrument developments have led to real-time concentration measurements using mobile analytical platforms performing several traverses across the plume, thus 
allowing one to quickly adjust the traverse location in response to changes in wind direction (Scheutz et al., 2011). The TDM has been applied at different area sources, including petrochemical refineries (Stiversten, 1983), natural gas facilities (Mitchell et al., 2015; Lamb et al., 1995), landfills (Börjesson et al., 2009; Foster-Wittig et al., 2015; Mønster et al., 2015; 2014), biological waste treatment facilities (Andersen et al., 2010; Jensen et al., 2017; Reinelt et al., 2017) and wastewater treatment plants (Delre et al., 2017; Yoshida et al., 2014; Yver Kwok et al., 2015).

Previous studies applied various tracer gases and analytical instruments (Galle et al., 2001; Lamb et al., 1995; Mosher et al., 1999; Mønster et al., 2014; Scheutz et al., 2011; Stiversten, 1983), but their performances in terms of plume description (e.g. peak height, signal-to-noise ratio, etc.) and emission rate quantification were never compared directly. The TDM was investigated in previous studies by performing a controlled release test (Mønster et al., 2014) and numerical simulations (Taylor et al., 2016), focusing on the importance of tracer gas placement, minimum measurement distance and ways to obtain the tracer to target gas concentration ratio (Mønster et al., 2014; Taylor et al., 2016).

This study investigates the influence of analytical instrument properties and tracer gas species on the TDM results, to outline the properties of the most suitable analytical instrument for TDM application. For this purpose, plant-integrated methane emissions from a wastewater treatment plant were measured simultaneously, using different analytical instruments with varying precisions and measurement frequencies as well as different tracer gases. Furthermore, this study investigates the influence of tracer gas misplacement on methane emission quantification. 


\section{Materials and methods}

\subsection{Site description}

The TDM was applied at a wastewater treatment plant near Lund, Sweden (Section S1 in the Supplementary Material (SM)), which treats about $11,290,000 \mathrm{~m}^{3}$ of wastewater annually, corresponding to a population equivalent (PE) of 120,000 . The plant is divided into three operational lines: a wastewater treatment line, a sewage sludge treatment line and a biogas line. The wastewater line involves mechanical treatments, activated sludge reactors for biological pollutant removal and an advanced form of treatment effected by flocculation and clarification ponds. Sewage sludge removed from the wastewater line is stabilised in the sludge line through anaerobic digestion, producing digestate and biogas. The digestate is dewatered and sent daily to an external facility, and the biogas is upgraded on-site and sold partly as vehicle fuel and partly to the natural gas supply grid.

\subsection{Application of the tracer gas dispersion method}

In this study, the TDM was applied using three vehicles equipped with analytical instruments, global navigation satellite system devices and monitors for real-time concentration readings. Atmospheric air was sampled continuously through tubes from the roofs of the vehicles and led to the analytical instruments, where gas concentrations were measured in real time. Prior to tracer gas release and methane emission quantification, off-site screenings were performed to ensure the absence of interfering sources in the vicinity of the plant. On-site screenings were used to identify the main methane sources at the facility for subsequent correct tracer gas placement at the centroid of the emitting area, thereby ensuring proper methane emission simulation. Tracer gases were released from gas cylinders using calibrated flowmeters, which were 
120 monitored continuously to guarantee constant flow rates. In addition, the weight loss

121 from the gas cylinders was measured and used for the methane emission rate

122 calculation. During emission quantification, downwind concentrations of methane and

123 tracer gases were measured by performing multiple traverses across the plume at

124 suitable downwind distances away from the plant - far enough to allow an appropriate

125 mixing of methane and tracer gases, and close enough for the analytical instrument to

126 distinguish the plume from the background concentration. Vehicle speeds were kept

127 constant during individual plume traversing, which was only considered successful if

128 the plume was completely crossed and the background concentration identified on both

129 sides of the plume (Fig. 1). Further details on TDM application can be found in the

130 literature (Delre et al., 2017; Mønster et al., 2014).

131 The fugitive methane emission rate was calculated for each plume traverse by

132 following the formula:

$E_{C H_{4}}=Q_{t r} \cdot \frac{\int_{\text {plume start }}^{\text {plume end }} C_{C H_{4}} d x}{\int_{\text {plume end }}^{\text {plume }} C_{t r} d x} \cdot \frac{M W_{C H_{4}}}{M W_{t r}}$

where $E_{\mathrm{CH}_{4}}$ is methane emission in mass per time; $Q_{t r}$ is tracer gas release in mass

135 per time; $C_{C_{4}}$ and $C_{t r}$ are measured downwind concentrations of methane and tracer

136 gas in parts per billion (ppb) above the plume traverse baseline (Fig. 1); $M W_{C_{4}}$ and

$137 M W_{t r}$ are the molecular weights of the methane and tracer gas, respectively (Scheutz et

138 al., 2011). Methane and tracer gas concentrations were integrated over the plume

139 detected in the plume traverse (Fig. 1) so that possible improper target and tracer gasses

140 mixing, and possible improper emitting source simulation would be minimised

141 (Mønster et al., 2014). 
In this study, methane and tracer gas plume traverses were described through four parameters: peak height $(\mathrm{PH})$, the Gaussian coefficient (GC), the signal-to-noise ratio

144 (SNR), and the plume correlation factor $\left(\mathrm{R}^{2}\right)$. $\mathrm{PH}$ is the maximum concentration above

145 the baseline measured in the plume (Fig. 1), while GC is the coefficient of

146 determination of the fitted Gaussian curve on the measured plume concentrations. GC

147 ranges between 0 and 1 , and the closer the plume shape is to Gaussian distribution, the

148 higher the GC is. The SNR indicates how well within a traverse the plume can be

149 distinguished from the background concentration. The SNR is calculated as suggested

150 by Shrivastava and Gupta (2011):

$151 S N R=\frac{P H}{0.5 h}$

152 where $\mathrm{h}$ is the difference between the highest and the lowest background concentrations (Fig. 1). Finally, $\mathrm{R}^{2}$ is the coefficient of determination of the linear

154 regression of methane-to-tracer gas concentrations within a plume traverse, and thus $\mathrm{R}^{2}$

155 ranges between 0 and 1 . It indicates how well methane and tracer gases are mixed in the

156 plume. $\mathrm{R}^{2}$ and GC were calculated using a build-in function of OriginPro $2016 \stackrel{(}{\circledR}$

157 (OriginLab, 2016).

\subsection{Analytical instruments and tracer gases}

159 Plant-integrated methane emissions from the wastewater treatment plant were 160 quantified using four tracer gases (acetylene, ethene, nitrous oxide and propane) and

161 measured with four analytical instruments (A, B, C and D) installed in three vehicles

162 (AB, C and D). Two cavity ring-down spectroscopy analysers were placed in vehicle

$163 \mathrm{AB}$, namely analytical instrument $\mathrm{A}$, which simultaneously measured acetylene and 164 methane (G2203, Picarro, Inc., Santa Clara, CA), and analytical instrument B, which 165 measured acetylene and nitrous oxide (S/N JADS2001, Picarro, Inc., Santa Clara, CA) 
166 (Mønster et al., 2014; Yoshida et al., 2014). Vehicle C contained analytical instrument

167 C, which was a Fourier Transform infrared spectroscopy analyser (IRCube Matrix-M,

168 Bruker Optics GmbH, Ettlingen, Germany) for the simultaneous measurement of

169 acetylene, ethene, methane, nitrous oxide and propane (Galle et al., 2001; Scheutz et al.,

170 2011). Vehicle D contained analytical instrument $D$, which was the same model as

171 analytical instrument A. Table 1 provides an overview of measured gases, analytical

172 instrument properties and gas release rates during the two tests in the measurement

173 campaign. Although activated sludge reactors at wastewater treatment plants are known

174 to emit nitrous oxide, emissions during the measurement campaign were below the

175 TDM detection limit $\left(0.4 \mathrm{~kg} \mathrm{~N}_{2} \mathrm{O} \mathrm{h}^{-1}\right)$, corresponding to less than $2 \%$ of the nitrous

176 oxide release rate when nitrous oxide was used as a tracer gas (Table 1). The TDM

177 detection limit was calculated according to the literature (Delre et al., 2017).

178 On-site atmospheric pressure, atmospheric temperature and wind speed were

179 recorded at four metres above ground level by a weather station placed in open terrain

180 on the southern border of the plant.

181 2.4. Measurement campaign

182 The measurement campaign was performed at a wastewater treatment plant in

183 Lund (SE) during the night and between August $4^{\text {th }}$ and $5^{\text {th }}, 2016$. It was decided to

184 perform measurements during night-time due to the likelihood of lower atmospheric gas

185 dispersion and less interference by traffic. During the night, the vertical dilution in the

186 atmosphere of any gas emitted/released is usually lower than during the day. This means

187 that, at the same distance from the emitting/releasing location, the downwind signal of

188 the plume is stronger when the dilution is lower. This is an advantage when applying the

189 TDM because downwind measurements can be performed further away from the source, 
190 and still obtain a plume traverse where the plume is well distinguished from the

191 background (Fig. 1). Additionally, less traffic allows downwind measurements with a

192 speed independent from other vehicles using the same road.

193 The campaign consisted of two tracer gas release tests. In Test 1, four tracer gases

194 (acetylene, ethene, nitrous oxide and propane) were released from the sludge treatment

195 area (Fig. 2), which was identified as the main methane emission source at the plant

196 during on-site screening. In Test 2, acetylene and ethene were still released from the

197 sludge treatment area, but nitrous oxide and propane were placed at two opposite

198 locations away from the main methane source (Fig. 2). Test 1 lasted 1 hour and 20

199 minutes (from 21:45 to 23:05), while Test 2 lasted 2 hours (from 01:45 to 03:45).

200 During both tests, atmospheric pressure was about $1005.5 \mathrm{hPa}$, and atmospheric

201 temperature was about $16^{\circ} \mathrm{C}$. Wind speed, measured at $4 \mathrm{~m}$ above the ground, was

202 between 0.5 and $1 \mathrm{~m} \mathrm{~s}^{-1}$ during Test 1, and about $0.6 \mathrm{~m} \mathrm{~s}^{-1}$ during Test 2. During both

203 tests, wind direction changed, moving the plume between NE and N-NW from the plant.

204 Analytical instruments A, B and C traversed the plume together, while analytical

205 instrument D traversed the plume at different distances and at different driving speeds.

206 Instrument D measured only during Test 1. Analytical instruments A, B and C

207 performed 12 and 17 plume traverses in Test 1 and Test 2, respectively. Analytical

208 instrument D performed 18 plume traverses in Test 1. Fig. 2 shows the location of the

209 performed plume traverses (more details are available in Table S1 in the SM).

\section{$210 \quad$ 2.5. Release precision ratio (RPR)}

211 Table 1 reports the amount of tracer gas released in both tests, and introduces the

212 release precision ratio (RPR), which is the ratio between molar release $\left(\mathrm{mol} \mathrm{h}^{-1}\right)$ and

213 analytical instrument precision (ppb). RPR indicates the strength of the downwind 
214 signal for a given instrument and gas combination. A higher RPR is obtained using an

215 analytical instrument with good precision (low precision value) when the tracer gas

216 release rate is kept constant. Conversely, an analytical instrument with a specific

217 precision has a higher RPR for a given tracer gas when more of this tracer gas is

218 released. Therefore, when different analytical instruments simultaneously traverse the

219 plume at the same distance away from the source, analytical instruments' performances

220 can be compared using the RPR. Table 1 also reports the methane emission rates

221 measured using $\mathrm{A}_{-} \mathrm{C}_{2} \mathrm{H}_{2}$, which was the instrument and gas combination used in Test 1

222 and Test 2, where the tracer gas was correctly placed at the main methane emission

223 source.

224

225

3. Results and discussion

226

\subsection{Description of the plume traverses}

227

Fig. 3 shows the GC, PH and SNR of methane and tracer gas plume traverses measured simultaneously at the same distance away from the plant by instruments A, B and C. PHs were similar when different instruments measured the same gases at approximately the same time and the same distance. However, when the analytical instruments measured the same gas, higher GC and SNR were obtained for instrument and gas combinations with a higher RPR. This difference in plume description was

233 attributed to the RPR and not to the specific tracer gas, as shown in Fig. 3 through a

234 comparison of instruments B and C, measuring acetylene and nitrous oxide. Plume

235 traverses of acetylene and nitrous oxide had high GC and SNR when they were 236 measured by instrument and gas combinations with high RPR (e.g. B_ $\mathrm{C}_{2} \mathrm{H}_{2}$ and $\mathrm{C}_{-}$

$237 \mathrm{~N}_{2} \mathrm{O}$ in Fig. 3); conversely, plume traverses had low GC and SNR when RPR was low 
238 (e.g. $\mathrm{C}_{-} \mathrm{C}_{2} \mathrm{H}_{2}$ and $\mathrm{B} \_\mathrm{N}_{2} \mathrm{O}$ in Fig. 3). In other words, $\mathrm{GC}$ and SNR of plume traverses 239 measured in Test 1 by B_ $\mathrm{C}_{2} \mathrm{H}_{2}$ (RPR equal to 48 ) were on average $15 \%$ and $63 \%$ higher

240 than GC and SNR of plume traverses measured by $\mathrm{C}_{-} \mathrm{C}_{2} \mathrm{H}_{2}$ (RPR equal to 18),

241 respectively. Similarly, GC and SNR of plume traverses measured in Test 1 by $\mathrm{C}_{-} \mathrm{N}_{2} \mathrm{O}$

242 (RPR equal to 542) were on average $8 \%$ and $83 \%$ higher than GC and SNR of plume

243 traverses measured by B_ $\mathrm{N}_{2} \mathrm{O}$ (RPR equal to 18), respectively. Similar results were

244 obtained in Test 2. In general, higher GC was seen for instrument and gas combinations

245 with a higher RPR (Fig. 3). However, this result does not imply that a higher GC

246 produces better quantification measurements. This analysis only shows that the

247 description of a plume traverse depends on the used instrument gas combination. A high

248 RPR also resulted in a high SNR, which is important in order to distinguish the plume

249 from the background concentration in each plume traverse (Fig. 1). Furthermore, a high

250 SNR increases the accuracy of baseline determination and thus reduces errors in

251 determining emission rates caused when subtracting background concentrations (Eq. 1).

252 Fig. 4 shows the correlation values $\left(\mathrm{R}^{2}\right)$ of the methane and tracer gas plume

253 traverses obtained by different instrument and tracer gas combinations measuring

254 simultaneously and at the same distance away from the plant. Since all analytical

255 instruments had similar RPRs when detecting methane (Table 1), the instruments

256 differed by tracer gas RPR and detection frequency. When tracer gases were released

257 from the same location, analytical instruments and tracer gas combinations with high

258 RPR (e.g. A_ $\mathrm{C}_{2} \mathrm{H}_{2}$ in Test 1 and Test 2, and $\mathrm{C}_{-} \mathrm{N}_{2} \mathrm{O}$ in Test 1) gave high $\mathrm{R}^{2}$. Generally,

259 low $\mathrm{R}^{2}$-values were obtained when, in Test 2 , the placement of the two tracer gas

260 (nitrous oxide and propane) release points was moved away from the main methane

261 source (Fig. 4). However, exceptions were when the tracer gas became aligned with the 
262 methane emission source, due to changes in wind direction (e.g. nitrous oxide placed

263 about $150 \mathrm{~m}$ upwind of the main methane source and plume traverses performed along

264 NE_1100 (Test 2 in Fig. 2)).

265 The combination of wind speed, plume traverse distances, and correct tracer gas

266 placement resulted in a sufficient mixing of methane and tracer gases, which was

267 confirmed by the very high $\mathrm{R}^{2}$-value $(0.86-0.98)$ of $\mathrm{A}_{-} \mathrm{C}_{2} \mathrm{H}_{2}$ obtained in Tests 1 and 2

268 (Fig. 4). The instrument and gas combination $\mathrm{A}_{-} \mathrm{C}_{2} \mathrm{H}_{2}$ was used as an example because

269 this combination had a high RPR and acetylene was released from the main methane

270 source in both tests. In general, the other instrument and tracer gas combinations also

271 had high $\mathrm{R}^{2}$-values, the only exceptions were traverses where $\mathrm{R}^{2}$ was below 0.75 , which

272 were caused by a low RPR (Fig. 4). A previous study considered $\mathrm{R}^{2}$ high when it is

273 larger than 0.75 (Roscioli et al., 2015).

274 The influence of RPR on the description of the plume traverse was also addressed

275 by studying the 12 plume traverses recorded by analytical instrument $C$ in Test 1 . In this

276 case, the analysed plume traverses differed only by RPR, as analytical instrument C

277 measured all gases with the same frequency (Table 1). An analysis was performed

278 ranking SNR, GC and $\mathrm{R}^{2}$ of the plume traverses for all tracer gases. A low rank was

279 assigned to a low parameter value, whereas a high rank was assigned to a high

280 parameter value. Table 2 describes the ranking procedure and reports the ranking results

281 for all investigated parameters. This analysis confirmed that analytical instrument and

282 tracer gas combinations with higher RPRs provided plume traverses with higher SNR,

283 GC and $\mathrm{R}^{2}$ (Table 2: instrument $\mathrm{C}$ using nitrous oxide as tracer gas). 


\subsection{Plant-integrated methane emission quantifications}

Table 3 reports on plant-integrated methane emission quantifications, using

different instrument and tracer gas combinations when tracer gases were released from

287

the main methane-emitting source at the plant. The analysis included analytical instruments $\mathrm{A}, \mathrm{B}$ and $\mathrm{C}$, which traversed the plumes simultaneously and at the same distance away from the plant. Different instrument and tracer gas combinations provided emission rates between 8.7 and $11.3 \mathrm{~kg} \mathrm{~h}^{-1}$ in Test 1 , and between 6.5 and 10.2 $\mathrm{kg} \mathrm{h}^{-1}$ in Test 2 (Table 3). Considering emission rates from all instrument and tracer gas combinations in Table 3, the corresponding mean emission rate was $10.3 \mathrm{~kg} \mathrm{~h}^{-1}$ in Test 1, and $7.9 \mathrm{~kg} \mathrm{~h}^{-1}$ in Test 2 .

Emission rates obtained by individual instrument and tracer gas combinations differed from the mean emission rate by 1 to $15 \%$ in Test 1 , and by 4 to $18 \%$ in Test 2 (Table 3). The variation of the methane emission rates, through multiple plume traverses, was reported as standard error of means (SEM), which was between 3 and $6 \%$ in Test 1 , and was equal to $2 \%$ in Test 2 . The size of the SEM was caused by three factors: real variations in the methane emission rates from the plant, non-systematic measurement uncertainty and the number of samples (plume traverses). However, the individual contribution from the real variations and measurement uncertainty were not quantifiable.

Table 3 also compares emission rates obtained by each instrument and tracer gas combination with the emission rate obtained by $\mathrm{A} \_\mathrm{C}_{2} \mathrm{H}_{2}$, which was chosen as a reference because it had a high tracer gas RPR and acetylene was released from the main methane source in both tests. The difference in emission rates compared to the methane emission rates quantified by $\mathrm{A}_{-} \mathrm{C}_{2} \mathrm{H}_{2}$ tended to be larger with a lower tracer 
308

309

gas RPR, e.g. the highest emission rate difference (26\%) was seen when quantification was performed using $\mathrm{C}_{-} \mathrm{C}_{2} \mathrm{H}_{4}$, which had the lowest tracer gas RPR (16) (Table 3).

\subsection{Properties of a suitable analytical instrument}

Besides proper atmospheric gas transportation and mixing, the success of any TDM application is mainly a combination of three factors: the analytical instrument's detection frequency, the analytical instrument's precision in measuring target and tracer gas, and the tracer and target gas release/emission rates. A suitable analytical instrument should have good precision and sufficient high detection frequency. Regarding precision, an analytical instrument with good precision can distinguish the plume better from the background concentration than an instrument with poor precision. Good instrument precision becomes important when measurements are performed in unfavourable conditions, i.e. situations with high atmospheric dispersion. Furthermore, better precision allows for measurements at a greater distance away from the source, thereby increasing the chance of having fully mixed conditions in the plume at the measurement distance. Additionally, a more precise analytical instrument allows a lower tracer gas release rate. An example is reported in Table 1, illustrating analytical instruments $\mathrm{B}$ and $\mathrm{C}$ measuring nitrous oxide. In Test 1, an nitrous oxide release rate of $16.7 \mathrm{~kg} \mathrm{~h}^{-1}$ was just enough to produce an RPR of 18 for instrument $\mathrm{B}$, whereas it produced an RPR equal to 542 for instrument C. Releasing less nitrous oxide, however, would have lowered the RPR of the plume traverses measured by both instruments, thereby resulting in very low RPRs for instrument B and still high RPRs for instrument C (Table 1). Additionally, a lower tracer gas release rate permits longer measurement periods without replacing tracer gas cylinders, thus resulting in lower costs. The use of an analytical instrument with poor tracer gas precision is still possible, though, by 
332 increasing the release rate of the tracer gas, with the consequence of a higher RPR. The

333 use of an analytical instrument with poor target gas precision, however, may be impossible in some cases. An instrument with better target gas precision allows for quantifying smaller emission rates than an instrument with a worse target gas precision. An analytical instrument with high frequency has three important benefits. First, it provides a more defined plume within the traverse, making it easier to distinguish the studied plume from other interfering sources, which would be seen as additional peaks/plumes (Fig. S2 in SM). Second, an analytical instrument with a higher detection frequency can perform more plume traverses within a specific time interval, thus obtaining an emission rate with smaller variation (SEM). An example of this is given in Table 3, showing a smaller SEM in Test 2 than in Test 1, where 17 and 12 plume traverses were performed, respectively. Third, an analytical instrument with a higher detection frequency can reduce the measurement time required and thus reduce costs.

\subsection{Tracer gas placement and emission source simulation}

In Test 2, nitrous oxide and propane were moved from the main on-site methane source, as shown in Fig. 3, to study the importance of tracer gas placement in the application of the TDM. Acetylene and ethene were still released from the main methane source, in order to simulate methane emissions properly. The analysis of the tracer gas placement was carried out on 12 plume traverses, performed by analytical instrument $\mathrm{C}$ along NE_1100 (Fig. 2), so that emission rates would be calculated using the same instrument performing the most plume traverses at the same distance. Nitrous oxide was misplaced about $150 \mathrm{~m}$ upwind, whereas propane was misplaced about $250 \mathrm{~m}$ sideward (Fig. 2). The tracer gas misplacement was measured from the centroid of the methane emitting area, which was approximately $1,250 \mathrm{~m}^{2}$ large (considering the sludge 
treatment line). Table 4 presents the results of the tracer gas placement analysis. The mean methane emission rate obtained using acetylene $\left(\mathrm{C}_{2} \mathrm{H}_{2}\right)$ and ethene $\left(\mathrm{C}_{2} \mathrm{H}_{4}\right)$, which were correctly placed, was $6.7 \mathrm{~kg} \mathrm{~h}^{-1}$. Methane emission rates obtained with combinations $\mathrm{C}_{-} \mathrm{C}_{2} \mathrm{H}_{2}$ and $\mathrm{C}_{-} \mathrm{C}_{2} \mathrm{H}_{4}$ differed by only $9 \%$ from the mean emission rate (Table 4). When the tracer gas was misplaced about $250 \mathrm{~m}$ sideward $\left(\mathrm{C}_{-} \mathrm{C}_{3} \mathrm{H}_{8}\right)$, the methane emission rate was comparable to those quantified using correct tracer gas placement (Table 4). Conversely, a high methane emission rate overestimation (almost $50 \%$ ) was obtained when the tracer gas was misplaced about $150 \mathrm{~m}$ upwind, due to different travel distances for the methane and the tracer gas, which resulted in higher tracer gas dispersion compared to methane $\left(\mathrm{C}_{-} \mathrm{N}_{2} \mathrm{O}\right.$ in Table 4). These findings are in line with previous studies highlighting the importance of tracer gas placement and the ability to minimise errors caused by a sideward misplacement when applying Eq. 1 rather than other formulas for emission rate quantifications (Mønster et al., 2014; Taylor et al., 2016). When tracer gases were placed correctly $\left(\mathrm{C}_{-} \mathrm{C}_{2} \mathrm{H}_{2}\right.$ and $\left.\mathrm{C}_{-} \mathrm{C}_{2} \mathrm{H}_{4}\right)$, the variation $(\mathrm{SEM})$ of the emission rates was smaller than variation reported using misplaced tracer gases $\left(\mathrm{C}_{-} \mathrm{C}_{3} \mathrm{H}_{8}\right.$ and $\left.\mathrm{C}_{-} \mathrm{N}_{2} \mathrm{O}\right)$ (Table 4). The overestimation and increased variation indicated that emission rates obtained through proper emission simulation are more accurate and precise than emission rates obtained through poor emission simulation.

\subsection{Varying measurement team}

Each measurement team (person or persons operating each analytical instrument) decided on measurement distances, vehicle speeds, etc. mainly based on previous experiences using their respective analytical instruments. During Test 1, analytical instrument D performed 18 plume traverses at other distances, driving speeds, etc. in the 
same time interval as the other analytical instruments (Table S1 in SM), which

381

382

383

384

385

386

387

388

389

390

391

392

393

394

395

396

397

398

performed 12 plume traverses. As reported in Table 1, instrument D had higher

detection frequency and better acetylene precision than instrument $\mathrm{C}$. These properties

allowed the collection of more plume traverses, and plume traverse measurements

further away (e.g. NNW_1900) (Table S1). The methane emission rate obtained with the instrument and tracer gas combination $\mathrm{D}_{-} \mathrm{C}_{2} \mathrm{H}_{2}$ was $10.6 \mathrm{~kg} \mathrm{~h}^{-1}$, which was similar to the emission rates measured in closer vicinity to the plant with instrument and tracer gas combinations with high RPRs reported in Table $3\left(\mathrm{C}_{-} \mathrm{N}_{2} \mathrm{O}: 11.0 \mathrm{~kg} \mathrm{~h}^{-1}, \mathrm{C}_{-} \mathrm{C}_{2} \mathrm{H}_{2}\right.$ :

$\left.10.2 \mathrm{~kg} \mathrm{~h}^{-1}\right)$. This result demonstrated a negligible difference in emission rate quantification when different measurement teams measured in the same time interval, even when using different instruments allowing collection of different numbers of plume traverses at different distances from the emission source.

\section{Conclusions}

The tracer gas dispersion method (TDM) was applied at a wastewater treatment plant to investigate the influence of analytical instrument properties and tracer gas species on TDM results. Plant-integrated methane emissions were quantified simultaneously using four analytical instruments with varying precisions and detection frequencies, as well as four tracer gases. Two tracer gas releasing tests were carried out. In Test 1, all tracer gases were released from the main on-site methane-emitting source, to simulate correctly emissions from the plant. In Test 2, two tracer gases were still correctly placed, while the other two were moved to two places opposite to the main onsite methane-emitting source, thereby allowing for investigating the effect of tracer gas misplacement on the methane emission rate. 
ratio between the tracer gas release rate and instrument precision (high tracer gas release precision ratio (RPR)) resulted in well-defined plumes close to a theoretical Gaussian atmospheric plume dispersion (a Gaussian coefficient closer to 1), and with a high signal-to-noise ratio (SNR) - the latter reducing the risk of over- or underestimating the 409 plume baseline, which is important for calculating the target gas emission rate. Finally,

410 an instrument and tracer gas combination with a high release precision ratio provided

411 plume traverses with a higher methane-to-tracer gas correlation factor $\left(\mathrm{R}^{2}\right)$, thereby

412 indicating better mixing between the two gases at the measurement point.

$413 \quad$ Measured plant-integrated methane emission rates varied between 8.7 and $11.3 \mathrm{~kg}$

$414 \mathrm{~h}^{-1}$ in Test 1 , and between 6.5 and $10.2 \mathrm{~kg} \mathrm{~h}^{-1}$ in Test 2 , when measurements were

415 performed under the same conditions (distance and tracer gas release configuration) but

416 using seven different instrument and tracer gas combinations. Methane emission rates

417 differed from the mean value by up $15 \%$ in Test 1 , and by up to $18 \%$ in Test 2.

418 A suitable analytical instrument for TDM application should preferably have good

419 precision and high detection frequency when measuring target and tracer gas. It is

420 important that the combination of an analytical instrument and tracer gas release can

421 produce a high RPR, as this will result in a high SNR. Setting aside cost and

422 environmental issues, the choice of tracer gas species is not important. As long as tracer 423 gas release and analytical instrument precision can produce a high SNR, any long-lived 424 atmospheric gas can be used as a tracer gas in the TDM application. However, it should 425 be emphasised that costs and environmental effects vary highly between different 426 potentially usable tracer gas species, whereby the choice of tracer gas should be done 427 considering those factors. 
The analysis of tracer gas misplacement showed that an upwind misplacement of

429

430

431

432

433

434

435

436

437

438

439

440

441

442

443

444

445

446

447

448

449

450

451

about $150 \mathrm{~m}$ led to an overestimation of the plant-integrated emission rate by almost

$50 \%$. Conversely, a sideward misplacement of about $250 \mathrm{~m}$ led to an emission rate

comparable to quantifications obtained using a tracer gas correctly simulating the

methane emission source.

Finally, a $4 \%$ difference in emission rate quantification was found when three measurement vehicles measured in the same time interval using four different instruments, which allowed for the collection of different numbers of plume traverses at different distances away from the plant.

\section{Acknowledgements}

This work was funded in part by the Innovation Fund Denmark (IFD) (Project

LaGAS, File No. 0603-00523B) and Veolia Water Technologies (Krüger,

AnoxKaldnes, The Veolia Group). Support from the wastewater utilities (Biofos, DK;

VA SYD, SE; Lyngby-Taarbæk forsyning, DK; FORS A/S, DK; Växjö, SE) and

Unisense Environment, DK, is acknowledged. The authors wish to thank the plant managers for their assistance during the whole study as well as staff at the plant for facilitating the measurements.

\section{Supplementary Material}

The Supplementary Material (SM) contains detailed information about the investigated site, quantifying analytical instrument precision, the measurement campaign, analytical instrument detection frequency and plant-integrated methane emission factors. 


\section{References}

454

455

456

457

458

459

460

461

462

463

464

465

466

467

468

469

470

471

472

473

474

Andersen, J.K., Boldrin, A., Christensen, T.H., Scheutz, C., 2010. Greenhouse gas emissions from home composting of organic household waste. Waste Manag. 30, 2475-2482. doi:10.1016/j.wasman.2010.07.004

Börjesson, G., Samuelsson, J., Chanton, J., Adolfsson, R., Galle, B., Svensson, B., 2009. A national landfill methane budget for Sweden based on field measurements, and an evaluation of IPCC models. Tellus 61B, 424-435. doi:10.1111/j.16000889.2008.00409.x

Delre, A., Mønster, J., Scheutz, C., 2017. Greenhouse gas emission quantification from wastewater treatment plants, using a tracer gas dispersion method. Sci. Total Environ. 605-606, 258-268. doi:10.1016/j.scitotenv.2017.06.177

DEPA, 2016. Danish Environmental Protection Agency Website about Biocover project (accessed July 22, 2017) [WWW Document]. URL http://mst.dk/affaldjord/affald/deponering/biocover-tilskudsordning/afrapportering-ogdokumentationskrav/

Foster-Wittig, T. A., Thoma, E.D., Green, R.B., Hater, G.R., Swan, N.D., Chanton, J.P., 2015. Development of a mobile tracer correlation method for assessment of air emissions from landfills and other area sources. Atmos. Environ. 102, 323-330. doi:10.1016/j.atmosenv.2014.12.008

Galle, B., Samuelsson, J., Svensson, B.H., Borjesson, G., 2001. Measurements of methane emissions from landfills using a time correlation tracer method based on FTIR absorption spectroscopy. Environ. Sci. Technol. 35, 21-25. 
IPCC, 2013: Climate Change 2013: The Physical Science Basis. Contribution of Working Group I to the Fifth Assessment Report of the Intergovernmental Panel on Climate Change [Stocker, T.F., D. Qin, G.-K. Plattner, M. Tignor, S.K. Allen, J. Boschung, A. Nauels, Y. Xia, V. Bex and P.M. Midgley (eds.)]. Cambridge University Press, Cambridge, United Kingdom and New York, NY, USA, 1535 pp.

Jakober, C. A., Mara, S.L., Hsu, Y.-K., Herner, J.D., 2014. Mobile measurements of climate forcing agents: Application to methane emissions from landfill and natural gas compression. J. Air Waste Manage. Assoc. 65, 404-412. doi:10.1080/10962247.2014.996269

Jensen, M.B., Møller, J., Mønster, J., Scheutz, C., 2017. Quantification of greenhouse gas emissions from a biological waste treatment facility. Waste Manag. 67, 375-384. doi: 10.1016/j.wasman.2017.05.033

Lamb, B.K., Mcmanus, J.B., Shorter, J.H., Kolb, C.E., Mosher, B., Allwine, E., Blaha, D., Westberg, H.A.L., Zimmerman-, P.A.T., 1995. Development of atmospheric tracer methods to measure methane emissions from natural gas facilities and urban areas. Environ. Sci. Technol. 29, 1468-1479.

Mitchell, A.L., Tkacik, D.S., Roscioli, J.R., Herndon, S.C., Yacovitch, T.I., Martinez, D.M., Vaughn, T.L., Williams, L.L., Sullivan, M.R., Floerchinger, C., Omara, M., Subramanian, R., Zimmerle, D., Marchese, A.J., Robinson, A.L., 2015. Measurements of methane emissions from natural gas gathering facilities and processing plants: measurement results. Environ. Sci. Technol. 3219-3227. doi:10.1021/es5052809

497 Mosher, B.W., Czepiel, P.M., Harriss, R.M., Shorter, J.H., Kolb, C.E., Mcmanus, J.B., 498 Allwine, E., Lamb, B., 1999. Methane emissions at nine landfill sites in the 

doi:10.1021/es981044z

Mønster, J., Samuelsson, J., Kjeldsen, P., Rella, C.W., Scheutz, C., 2014. Quantifying methane emission from fugitive sources by combining tracer release and downwind measurements - a sensitivity analysis based on multiple field surveys. Waste Manag. 34, 1416-1428. doi:10.1016/j.wasman.2014.03.025

Mønster, J., Samuelsson, J., Kjeldsen, P., Scheutz, C., 2015. Quantification of methane emissions from 15 Danish landfills using the mobile tracer dispersion method. Waste Manag. 35, 177-186. doi:10.1016/j.wasman.2014.09.006

OriginLab 2016 - Software for data processing OriginPro $2016{ }^{\circledR}$ version b9.3.1.273 (Academic) - available at http://www.OriginLab.com (last accessed March $15^{\text {th }}$, 2018).

Reinelt, T., Delre, A., Westerkamp, T., Holmgren, M.A., Liebetrau, J., Scheutz, C., 2017. Comparative use of different emission measurement approaches to determine methane emissions from a biogas plant. Waste Manag. 68, 137-185.

514 Roscioli, J.R., Yacovitch, T.I., Floerchinger, C., Mitchell, A. L., Tkacik, D.S.,

515 Subramanian, R., Martinez, D.M., Vaughn, T.L., Williams, L., Zimmerle, D.,

516 Robinson, a. L., Herndon, S.C., Marchese, a. J., 2015. Measurements of methane

517 emissions from natural gas gathering facilities and processing plants: measurement

518 methods. Atmos. Meas. Tech. 8, 2017-2035. doi:10.5194/amt-8-2017-2015

519 Scheutz, C., Samuelsson, J., Fredenslund, A M., Kjeldsen, P., 2011. Quantification of

520 multiple methane emission sources at landfills using a double tracer technique. 
522 Shrivastava, A., Gupta, V., 2011. Methods for the determination of limit of detection

523 and limit of quantitation of the analytical methods. Chronicles Young Sci. 2, 21-25.

524 doi:10.4103/2229-5186.79345

525 Stiversten, B., 1983. Estimation of diffuse hydrocarbon leakages from petrochemical 526 factories. Air Pollut. Control Assoc. 33, 323-327.

527 Taylor, D.M., Chow, F.K., Delkash, M., Imhoff, P.T., 2016. Numerical simulations to 528 assess the tracer dilution method for measurement of landfill methane emissions.

529 Waste Manag. 56, 298-309. doi:10.1016/j.wasman.2016.06.040

530 Yoshida, H., Mønster, J., Scheutz, C., 2014. Plant-integrated measurement of

531 greenhouse gas emissions from a municipal wastewater treatment plant. Water Res.

$532 \quad 61,108-118$. doi:10.1016/j.watres.2014.05.014

533 Yver Kwok, C.E., Müller, D., Caldow, C., Lebègue, B., Mønster, J.G., Rella, C.W.,

534 Scheutz, C., Schmidt, M., Ramonet, M., Warneke, T., Broquet, G., Ciais, P., 2015.

535 Methane emission estimates using chamber and tracer release experiments for a

536 municipal waste water treatment plant. Atmos. Meas. Tech. 8, 2853-2867.

537 doi:10.5194/amt-8-2853-2015 
FIGURES

540

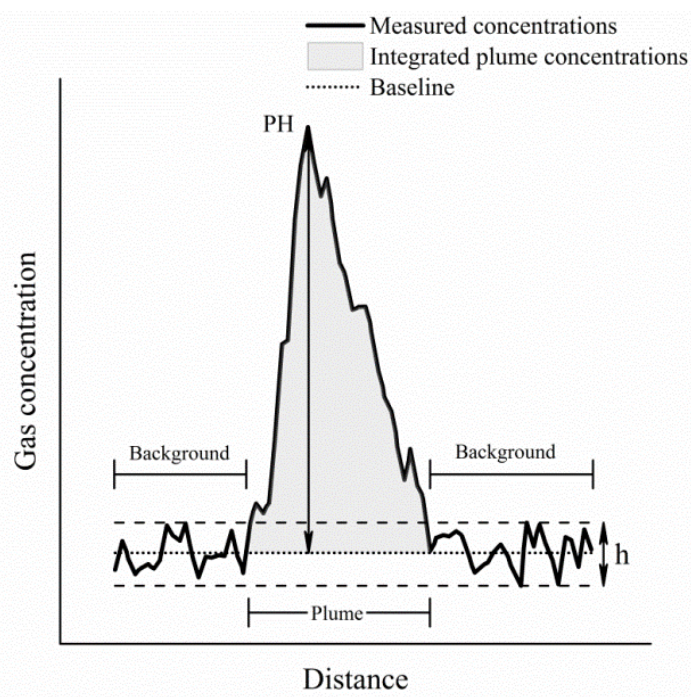

541 Fig. 1. Example of a plume traverse, showing baseline, background concentration, peak 542 height $(\mathrm{PH})$ and integrated plume concentrations. 

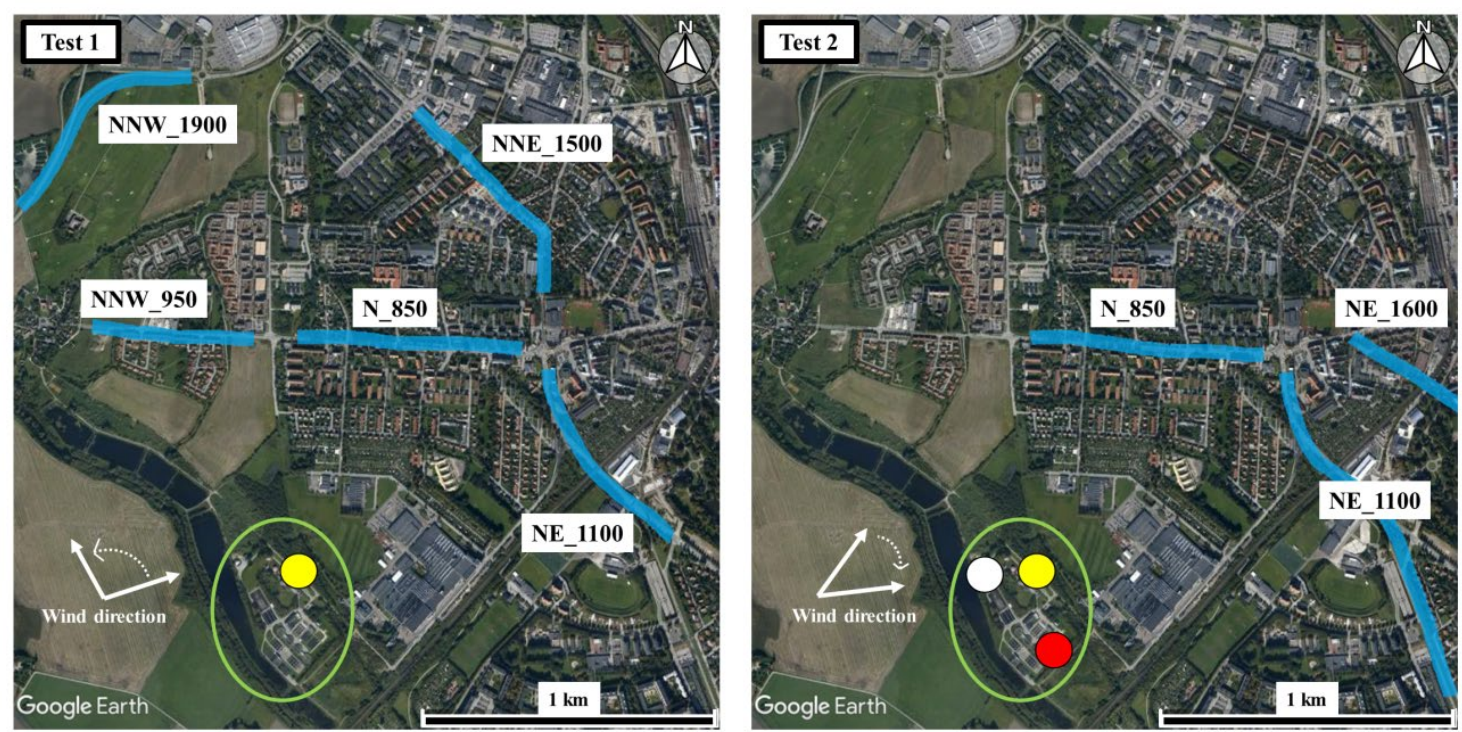

544 Fig. 2. Plume traverse positions during Test 1 and Test 2 are marked with blue lines. 545 Plume traverse positions are named using cardinal directions and distance $(\mathrm{m})$ away 546 from the sludge treatment area of the wastewater treatment plant. In Test 1, the tracer 547 gas release location is marked with a yellow circle for all tracer gases. In Test 2, the 548 tracer gas release location is marked with a yellow circle for acetylene and ethene, with 549 white and red circles for nitrous oxide and propane, respectively. The wastewater 550 treatment plant is marked with a green circle. 
Test 1
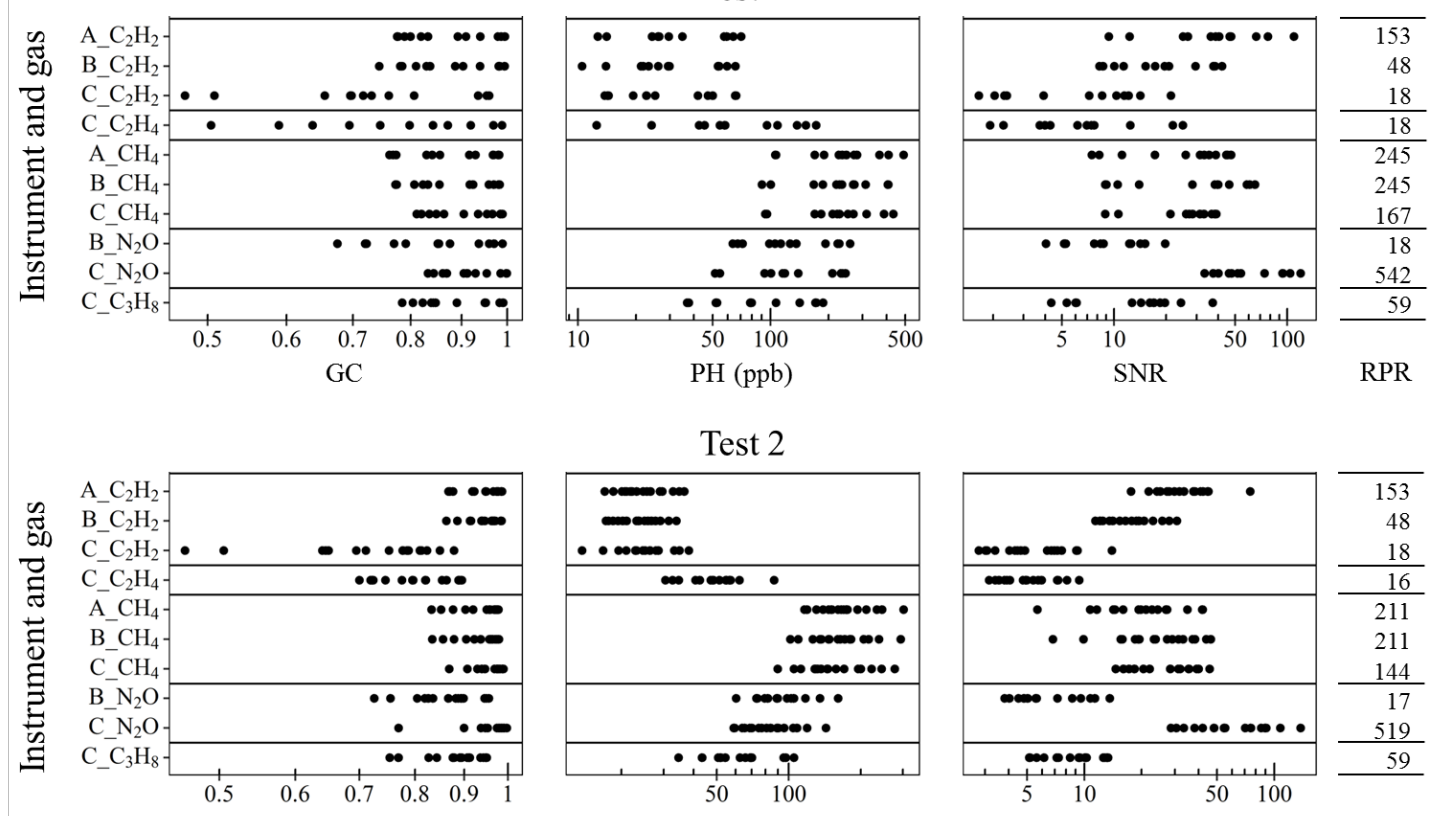

Test 2

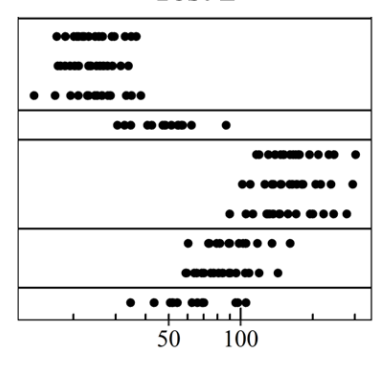

PH (ppb)

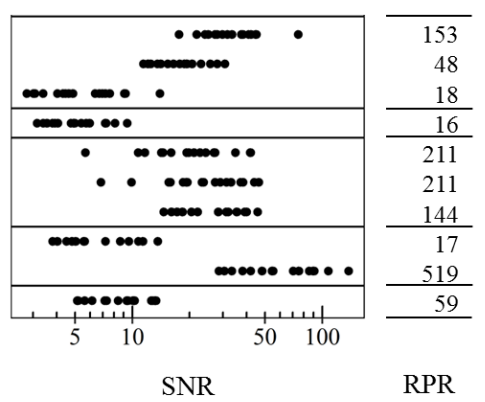

552 Fig. 3. Description of plume traverses performed simultaneously at the same distance away from the plant by analytical instruments A, B and C. Parameters shown include the Gaussian coefficient (GC), peak height (PH), and signal-to-noise-ratio (SNR). RPR stands for "release precision ratio." A description of all instrument and gas combinations is available in Table 1. 

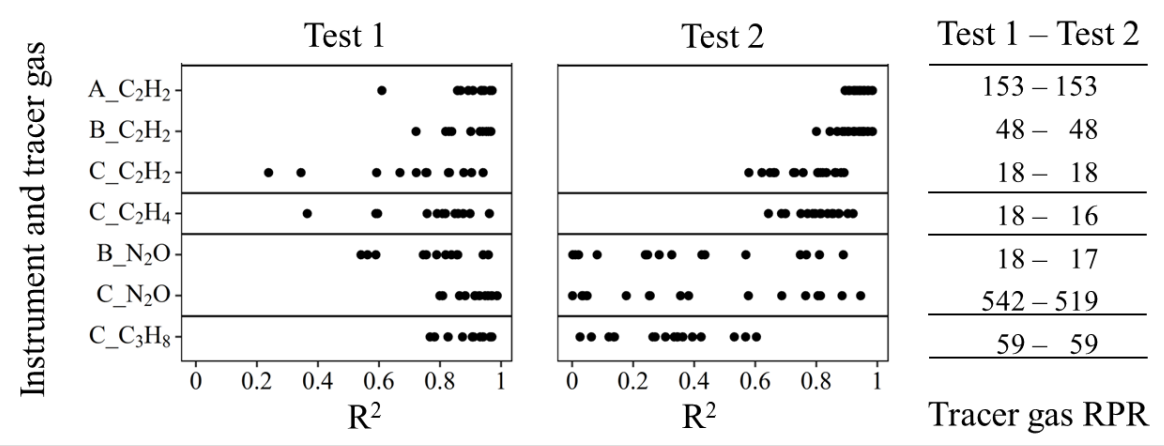

558 Fig. 4. Methane and tracer gas plume traverse correlation factor $\left(\mathrm{R}^{2}\right)$ of all analytical 559 instrument and tracer gas combinations measuring simultaneously and at the same 560 distance away from the plant. RPR stands for "release precision ratio." 
Paper intended for publication in Science of the Total Environment

561 Table 1. Measured gases, analytical instrument properties and gas release rates during the two test campaigns.

\begin{tabular}{|c|c|c|c|c|c|c|c|c|c|c|}
\hline \multicolumn{2}{|c|}{ Gas } & \multicolumn{3}{|c|}{ Analytical instrument properties } & \multicolumn{4}{|c|}{ Gas release rate } & \multirow{2}{*}{\multicolumn{2}{|c|}{$\begin{array}{c}\text { Release } \\
\text { precision ratio } \\
(\mathrm{RPR}) \\
\left(\mathrm{mol} \mathrm{h}^{-1} \mathrm{ppb}^{-1}\right)\end{array}$}} \\
\hline \multirow[t]{2}{*}{$\begin{array}{l}\text { Name and } \\
\text { chemical } \\
\text { formula }\end{array}$} & \multirow[t]{2}{*}{$\begin{array}{l}\text { Molecular } \\
\text { weight } \\
\left(\mathrm{g} \mathrm{mol}^{-1}\right)\end{array}$} & \multirow[t]{2}{*}{ Instrument and gas } & \multirow[t]{2}{*}{$\begin{array}{l}\text { Frequency } \\
(\mathrm{Hz})\end{array}$} & \multirow[t]{2}{*}{$\begin{array}{l}\text { Precision } \\
\quad(\mathrm{ppb})\end{array}$} & \multicolumn{2}{|c|}{$\begin{array}{l}\text { Mass release } \\
\quad\left(\mathrm{kg} \mathrm{h}^{-1}\right)\end{array}$} & \multicolumn{2}{|c|}{$\begin{array}{l}\text { Molar release } \\
\quad\left(\mathrm{mol} \mathrm{h}^{-1}\right)\end{array}$} & & \\
\hline & & & & & Test 1 & Test 2 & Test 1 & Test 2 & Test 1 & Test 2 \\
\hline & & $\mathrm{A}_{-} \mathrm{C}_{2} \mathrm{H}_{2}$ & 2 & 0.5 & & & & & 153 & 153 \\
\hline Acetylene & 26 & B_- $\mathrm{C}_{2} \mathrm{H}_{2}$ & 0.3 & 1.6 & 20 & 20 & 77 & 77 & 48 & 48 \\
\hline $\mathrm{C}_{2} \mathrm{H}_{2}$ & 20 & $\mathrm{C}_{-}^{-} \mathrm{C}_{2} \mathrm{H}_{2}$ & 0.06 & 4.2 & 2.0 & 2.0 & 77 & 77 & 18 & 18 \\
\hline & & $\mathrm{D}_{-}^{-} \mathrm{C}_{2} \mathrm{H}_{2}$ & 2 & 0.3 & & & & & 256 & NA \\
\hline $\begin{array}{c}\text { Ethene } \\
\mathrm{C}_{2} \mathrm{H}_{4}\end{array}$ & 28 & C_ $\mathrm{C}_{2} \mathrm{H}_{4}$ & 0.06 & 10.7 & 5.4 & 4.8 & 193 & 171 & 18 & 16 \\
\hline & & $\mathrm{A}_{-} \mathrm{CH}_{4}$ & 2 & 2.6 & & & & & 245 & 211 \\
\hline Methane & 16 & B_- $\mathrm{CH}_{4}$ & 0.3 & 2.6 & 102 & 88 & 6375 & 5500 & 245 & 211 \\
\hline $\mathrm{CH}_{4}$ & 10 & $\mathrm{C}_{-} \mathrm{CH}_{4}$ & 0.06 & 3.8 & 10.2 & 0.8 & 031.5 & 530.0 & 167 & 144 \\
\hline & & $\mathrm{D}_{-}^{-} \mathrm{CH}_{4}$ & 2 & 3.2 & & & & & 205 & NA \\
\hline Nitrous oxide & 44 & $\mathrm{~B} \_\mathrm{N}_{2} \mathrm{O}$ & 0.3 & 21.1 & 167 & 160 & 380 & 364 & 18 & 17 \\
\hline $\mathrm{N}_{2} \mathrm{O}$ & 44 & $\mathrm{C}_{-}^{-} \mathrm{N}_{2} \mathrm{O}$ & 0.06 & 0.7 & 10.1 & 16.0 & 380 & 364 & 542 & 519 \\
\hline $\begin{array}{c}\text { Propane } \\
\mathrm{C}_{3} \mathrm{H}_{8}\end{array}$ & 44 & $\mathrm{C}_{-} \mathrm{C}_{3} \mathrm{H}_{8}$ & 0.06 & 3.7 & 9.7 & 9.7 & 220 & 220 & 59 & 59 \\
\hline
\end{tabular}

A: Cavity ring down spectroscopy (CRDS) analyser detecting acetylene and methane placed in vehicle AB. B: CRDS analyser detecting acetylene and nitrous oxide placed in vehicle

AB. C: Fourier Transform infrared spectroscopy analyser detecting acetylene, ethene, methane, nitrous oxide, and propane placed in vehicle C. D: CRDS analyser detecting acetylene and methane placed in vehicle D. B_CH4 is methane measured with instrument A and coupled to tracer gases measured by instrument B. NA: Not available. The methane gas releases are the emission rates measured using $\mathrm{A}_{-} \mathrm{C}_{2} \mathrm{H}_{2}$ (the instrument and tracer gas combination used in Test 1 and Test 2, where the tracer gas was placed at the main methane emission source).

Precision is defined as three times the standard deviation of six minutes' constant concentration reading (Section S2 in SM). 
563 Table 2. Ranking results of parameters describing plume traverses in the analytical 564 instrument precision analysis. Gaussian coefficient (GC), signal-to-noise ratio (SNR) 565 and the plume correlation factor $\left(\mathrm{R}^{2}\right)$ are reported for the 12 plume traverses performed 566 by analytical instrument $\mathrm{C}$ in Test 1 .

\begin{tabular}{|c|c|c|c|c|}
\hline \multirow{2}{*}{ Tracer gas } & \multicolumn{3}{|c|}{ Rank } & \multirow{2}{*}{ RPR } \\
\hline & SNR & $\mathrm{GC}$ & $\mathrm{R}^{2}$ & \\
\hline $\mathrm{C}_{2} \mathrm{H}_{2}$ & 18 & 15 & 15 & 18 \\
\hline $\mathrm{C}_{2} \mathrm{H}_{4}$ & 20 & 22 & 23 & 18 \\
\hline $\mathrm{C}_{3} \mathrm{H}_{8}$ & 34 & 35 & 38 & 59 \\
\hline $\mathrm{N}_{2} \mathrm{O}$ & 48 & 48 & 44 & 542 \\
\hline
\end{tabular}

The ranking procedure was carried out by comparing the parameter values (GC, SNR and $\mathrm{R}^{2}$ ) of the four tracer gases

568 in each plume traverse. The tracer gas having the lowest and the highest parameter value scored 1 and 5 , respectively, 569 whereas the tracer gas with parameter values in between scored 2, 3, and 4, accordingly. The final score assigned to 570 each dataset was the sum of the scores of the 12 plume traverses. 
Paper intended for publication in Science of the Total Environment

Table 3. Plant-integrated methane emission quantifications using different instrument and tracer gas combinations when tracer gases were released from the main methane emitting source at the wastewater treatment plant.

\begin{tabular}{|c|c|c|c|c|c|c|c|c|c|c|c|c|}
\hline \multirow{3}{*}{$\begin{array}{l}\text { Instrument } \\
\text { and tracer gas } \\
\text { combination }\end{array}$} & \multirow{2}{*}{\multicolumn{2}{|c|}{$\begin{array}{c}\text { Test } 1 \\
\text { Emission rate }\end{array}$}} & \multirow{2}{*}{\multicolumn{2}{|c|}{$\begin{array}{c}\text { Test } 2 \\
\text { Emission rate }\end{array}$}} & \multicolumn{4}{|c|}{$\begin{array}{c}\text { Relative difference in emission rate } \\
\text { compared to the mean } \mathrm{CH}_{4} \text { emission rate } \\
\text { quantified by all combinations } \\
\left(10.3 \mathrm{~kg} \mathrm{~h}^{-1} \text { in Test } 1 \text {, and } 7.9 \mathrm{~kg} \mathrm{~h}^{-1} \text { Test } 2\right) \\
\end{array}$} & \multicolumn{2}{|c|}{$\begin{array}{c}\text { Relative difference in emission rate } \\
\text { compared to the } \mathrm{CH}_{4} \text { emission rate } \\
\text { quantified by } \mathrm{A}_{-} \mathrm{C}_{2} \mathrm{H}_{2}\end{array}$} & \multicolumn{2}{|c|}{ Tracer gas RPR } \\
\hline & & & & & \multicolumn{2}{|c|}{ Test 1} & \multicolumn{2}{|c|}{ Test 2} & \multirow{2}{*}{$\begin{array}{c}\text { Test } 1 \\
\text { Average } \\
(\%)\end{array}$} & \multirow{2}{*}{$\begin{array}{c}\text { Test } 2 \\
\text { Average } \\
(\%)\end{array}$} & \multirow[b]{2}{*}{ Test 1} & \multirow[b]{2}{*}{ Test 2} \\
\hline & $\begin{array}{c}\begin{array}{c}\text { Average } \\
\left(\mathrm{kg} \mathrm{h}^{-1}\right)\end{array} \\
\end{array}$ & $\begin{array}{c}\text { SEM } \\
\left(\mathrm{kg} \mathrm{h}^{-1}\right)\end{array}$ & $\begin{array}{c}\text { Average } \\
\left(\mathrm{kg} \mathrm{h}^{-1}\right)\end{array}$ & $\begin{array}{c}\text { SEM } \\
\left(\mathrm{kg} \mathrm{h}^{-1}\right)\end{array}$ & $\begin{array}{c}\text { Average } \\
(\%)\end{array}$ & $\begin{array}{c}\text { SEM } \\
(\%)\end{array}$ & $\begin{array}{c}\text { Average } \\
(\%)\end{array}$ & $\begin{array}{l}\text { SEM } \\
(\%)\end{array}$ & & & & \\
\hline $\mathrm{C}_{-} \mathrm{N}_{2} \mathrm{O}$ & 11.0 & 0.7 & NA & NA & 7 & 3 & NA & NA & 8 & NA & 542 & 519 \\
\hline A_ $\mathrm{C}_{2} \mathrm{H}_{2}$ & 10.2 & 0.8 & 8.8 & 0.3 & -1 & 4 & 11 & 2 & 0 & 0 & 153 & 153 \\
\hline $\mathrm{C}_{-} \mathrm{C}_{3} \mathrm{H}_{8}$ & 8.7 & 0.8 & NA & NA & -15 & 4 & NA & NA & -15 & NA & 59 & 59 \\
\hline B_ $\mathrm{C}_{2} \mathrm{H}_{2}$ & 10.6 & 0.9 & 8.7 & 0.3 & 3 & 4 & 10 & 2 & 4 & -1 & 48 & 48 \\
\hline C_ $\mathrm{C}_{2} \mathrm{H}_{2}$ & 9.1 & 0.8 & 7.6 & 0.3 & -12 & 4 & -4 & 2 & -11 & -13 & 18 & 18 \\
\hline C_ $\mathrm{C}_{2} \mathrm{H}_{4}$ & 11.3 & 1.2 & 6.5 & 0.3 & 10 & 6 & -18 & 2 & 11 & -26 & 18 & 16 \\
\hline B_ $\mathrm{N}_{2} \mathrm{O}$ & 11.2 & 0.7 & NA & NA & 9 & 4 & NA & NA & 10 & NA & 18 & 17 \\
\hline
\end{tabular}

574 The average emission rate was given as the average value of all plume traverses, and the corresponding variation of the methane emission rates, through multiple plume traverses, was

575 expressed as standard error of the means (SEM). Instrument and tracer gas combinations are ordered from the highest to the lowest RPR. NA: not applicable. Relative difference in

576 emission rate: (Measured emission rate - Average emission rate)/Average emission rate 
578 Table 4. Tracer gas placement analysis. Comparison of plant-integrated methane 579 emission rates using different tracer gas placements. Twelve plume traverses performed 580 in Test 2 by instrument $\mathrm{C}$ along NE_ 1100 were used.

\begin{tabular}{|c|c|c|c|c|c|}
\hline \multirow{2}{*}{$\begin{array}{l}\text { Instrument } \\
\text { and } \\
\text { tracer gas }\end{array}$} & \multirow{2}{*}{$\begin{array}{l}\text { Tracer gas } \\
\text { placement }\end{array}$} & \multicolumn{2}{|c|}{ Emission rate } & \multicolumn{2}{|c|}{$\begin{array}{l}\text { Relative difference in emission rate } \\
\text { compared to the mean emission rate } \\
\text { quantified with } \mathrm{C}-\mathrm{C}_{2} \mathrm{H}_{2} \text { and } \mathrm{C}-\mathrm{C}_{2} \mathrm{H}_{4}\left(6.7 \mathrm{~kg} \mathrm{~h}^{-1}\right)\end{array}$} \\
\hline & & $\begin{array}{c}\text { Average } \\
\left(\mathrm{kg} \mathrm{CH}_{4} \mathrm{~h}^{-1}\right)\end{array}$ & $\begin{array}{c}\mathrm{SEM} \\
\left(\mathrm{kg} \mathrm{CH}_{4} \mathrm{~h}^{-1}\right)\end{array}$ & $\begin{array}{c}\text { Average } \\
(\%)\end{array}$ & $\begin{array}{c}\text { SEM } \\
(\%)\end{array}$ \\
\hline C_ $\mathrm{C}_{2} \mathrm{H}_{2}$ & Correct & 7.3 & 0.4 & 9 & 3 \\
\hline C_ $\mathrm{C}_{2} \mathrm{H}_{4}$ & Correct & 6.1 & 0.4 & -9 & 3 \\
\hline $\mathrm{C}_{-} \mathrm{C}_{3} \mathrm{H}_{8}$ & Sideward misplacement & 7.5 & 0.7 & 12 & 5 \\
\hline C_ $\mathrm{N}_{2} \mathrm{O}$ & Upwind misplacement & 10.0 & 0.8 & 49 & 6 \\
\hline
\end{tabular}

581 Correct tracer gas placement was at the main on-site methane source.

582 The average emission rate was given as the average value of all plume traverses, and the corresponding variation of

583 the methane emission rates, through multiple plume traverses, was expressed as standard error of the means (SEM).

584 Relative difference in emission rate: (Measured emission rate - Average emission rate)/Average emission rate. 